\title{
Enzyme conductometric biosensor for maltose determination
}

\author{
V. M. Pyeshkova ${ }^{1,2}$, O. Y. Saiapina ${ }^{1}$, O. O. Soldatkin ${ }^{1}$, S. V. Dzyadevych ${ }^{1}$ \\ ${ }^{1}$ Institute of molecular biology and genetics NAS Ukraine, \\ 150 Zabolotnogo Str., Kyiv, Ukraine, 03143 \\ ${ }^{2}$ National Taras Shevchenko University of Kyiv, \\ 64 Volodymyrska Str., Kyiv, Ukraine, 01003 \\ victoriya@gmail.com
}

\begin{abstract}
Aim. To develop enzyme conductometric biosensor for maltose determination. Methods. A conductometric transducer consisting of two gold pairs of electrodes was applied. Three-enzyme mem-brane (glucose oxidase, mutarotase, $\alpha$-glucosidase) immobilized on the surface of the conductometric transducer was used as a bioselective element. Results. A linear range of maltose con-ductometric biosensor was from 0,002 $\mathrm{mM}$ to $1 \mathrm{mM}$ for glucose and maltose detection. The time of maltose analysis in solution was 1-2 minutes. The dependence of biosensor responses to substrate on $\mathrm{pH}$, ionic strength, and buffer capacity of work solution was studied. The data of biosensor selectivity are presented. The developed conductometric biosensor is characterized by high operational sta-bility and signal reproducibility. Conclusion. The enzyme conductometric biosensor for maltose determination has been developed. The analytical characteristics of the maltose biosensor were investigated. The proposed method could be used in food industry to control and optimize production.
\end{abstract}

Keywords: conductometric biosensor, maltose, mutarotase, glucose oxidase, $\alpha$-glucosidase.

Introduction. At present, maltose syrup is more and more applied in food industry because of its properties: sweetness, high thermostability, low hydroscopy and viscosity, absence of crystallization at storage; besides, maltose is energetically valuable, easily assimilated by organism. Comparing to other low-molecular carbohydrates, maltose syrup is the most effective compound preventing saccharose crystallization. Due to unique characteristics, maltose syrups are used at production of wide range of confectionery (caramel, frozen dairy produce, jellies, canned fruits, etc.). Besides, saccharose is frequently substituted for maltose in food manufacture, in particular, in

(C) Institute of Molecular Biology and Genetics NAS of Ukraine, 2009 production of child foodstuff, due to lower allergenicity of maltose. Maltose is used in manufacture of dietetic and sports foodstuff, bread, wine, preserves, beverages. Besides, maltose is utilized in microbiology and pharmacology [1].

In organism, maltose is decomposed to two glucose molecules due to activity of enzyme maltase ( $\alpha$-glucosidase) which presents in digestive juices of animals and humans. Genetically determined absence of maltase in mucous coat of human intestine causes congenital intolerance to maltose which is a severe disease and requires to eliminate maltose, starch and glycogen from the ration and to supplement it with maltase [2].

Hence, it is comprehensible that well-adjusted system for monitoring maltose concentration is necessary 
in food production and medicine. Besides, maltose is determined in enzymology and microbiology for monitoring the fermentation process. The modern standard methods of high-precision determination of maltose, i.e. gas and liquid chromatography, chemical and optical methods, require complex and expensive equipment served and maintained by highly qualified personnel [3]. Rather complicated pretreatment of samples to be analyzed is one more disadvantage of the above methods. Polarometry and refractometry, though simple and fast, are less precise and selective methods. In contrast, biosensors are easy-to-use, accurate, selective, quick, and inexpensive devices. This is why development of biosensors for maltose determination can facilitate and improve maltose monitoring in food production and medical diagnostics.

At present, there are a number of laboratory prototypes of biosensors for maltose analysis [3-14] with different enzymes immobilized on the electrode surface: amyloglucosidase and glucose oxidase [3-5]; amyloglucosidase, mutarotase, glucose oxidase and peroxidase [6]; $\alpha$-glucosidase and glucose oxidase [3, 7-9]; $\alpha$-glucosidase, mutarotase and glucose oxidase [10]; $\alpha$-glucosidase and glucose dehydrogenase [9, 11]; $\alpha$-glucosidase and glucokinase [12].

Working characteristics of the developed biosensors differ depending on the ratio between enzymes, and the kind of mediators and stabilizing agents in the bioselective membrane; type of transducers; and the method of immobilization of an enzymatic membrane on the electrode surface. For instance, the amperometric sensor system for simultaneous determination of maltose and glucose is reported to be developed on the basis of carbon electrodes [5]. Two enzymes, amyloglucosidase and glucose oxidase, were used for maltose measurement, and only glucose oxidase-for glucose. 1,1'-ferricyanide methanol served as a mediator. The solution with $3.5 \%$ hydroxyethylcellulose and 3\% polyethylene glycol was prepared for obtaining external membrane. Optimal $\mathrm{pH}$ of the sensor system was 4.8. Linear range of sensor operation remained up to $40 \mathrm{mM}$ glucose and $20 \mathrm{mM}$ maltose. The enzyme electrodes did not lose their activity during 4-month dry storage at $4^{\circ} \mathrm{C}$.

The amperometric biosensor for maltose analysis described in [10] is based on determination of activity of $\alpha$-amylase which hydrolyzes starch to maltose. The bioselective membrane on the electrode surface was formed by immobilization of glucose oxidase, mutarotase and $\alpha$-glucosidase with gelatine and BSA by means of glutaraldehyde. The biosensor is characterized by linear dependence of the response on maltose concentration within the range of $0.1-3 \mathrm{mM}$. The response time was $30 \mathrm{~s}$.

In [7] the authors inform about the amperometric enzyme biosensor for maltose determination in culture fluid aimed at research of fermentation followed by changes in maltose concentration. Influence of $\alpha$-glucosidase and amyloglicosidase on efficiency of transformation of maltose to glucose was studied and shown amyloglicosidase to be more helpful. This is why mixture of amyloglicosidase with glucose oxidase was used in the biosensor developed which enabled measurement of maltose concentration in culture fluids in the range of $0.2-4 \mathrm{mM}$.

There is an information on the amperometric multibiosensor for determination of several carbohydrates (maltose, lactose, saccharose and glucose) [3] and the potentiometric biosensors based on thermostable elements for simultaneous analysis of saccharose, maltose and glucose in solution [12].

Though most of developed biosensors for maltose determination are of amperometric type $[5,9,10,12]$ they have some disadvantages as compared to those of conductometric kind. First one is a high applied potential which results in error occurring because of the presence of other electrooxidizing components, e.g. ascorbic acid, in the solution. Second, they need technologically complicated and expensive reference electrodes. Third, Faraday processes on electrodes owing to high applied potential. Besides, amperometric biosensors are more expensive.

Basically, with regards to other electrochemical biosensors, conductometric biosensors are relatively simple, easy-to-use, precise, and useful in view of numerous research and commercial challenges $[15,16]$. The goal of this work was development of a conductometric enzyme biosensor for maltose determination and study on its working characteristics.

Materials and methods. Materials. The frozen-dried preparations of glucose oxidase (GOD) from Penicillium vitale (EC 1.1.3.4.) with activity of 
$130 \mathrm{U} / \mathrm{mg}$, production of "Diagnostikum" (Lviv, Ukraine), mutarotase (EC 5.1.3.3.) with activity of 100 $\mathrm{U} / \mathrm{mg}$, production of "Biozyme Laboratories Ltd" (Great Britain), $\alpha$-glucosidase (EC 3.2.1.20.) from $B a-$ cillus stearotermophilus with activity of $109 \mathrm{U} / \mathrm{mg}$, production of "Sigma-Aldrich Chemie” (Steinheim, Germany) were used. Bovine serum albumin (BSA) (fraction $\mathrm{V}$ ) and $50 \%$ aqueous solution of glutaraldehyde (GA) were also from "Sigma-Aldrich Chemie GmbH" (Steinheim, Germany). As substrates were maltose and glucose, "Merck" (Germany). Potassium-phosphate solution (KH2PO4-NaOH) manufactured in "Merck" (Germany) was used as a buffer solution. The rest inorganic compounds were of domestic manufacture, had analytical reagent grade and were used as received without additional purification.

We used conductometric transducers manufactured in V. Lashkaryov Institute of Semiconductor Physics NASU (Kyiv, Ukraine). They consist of two identical pairs of gold interdigitated electrodes obtained by vacuum sputtering of gold onto ceramized plate of $5 \times 40$ $\mathrm{mm}$. The sensitive surface of each pair was about 1.0 $\mathrm{mm} \times 1.5 \mathrm{~mm}$, the distance between neighbour digits, as well as the digit width were $20 \mu \mathrm{m}$.

Preparation of bioselective membranes. The enzymes in membrane were immobilized on the electrodes surface by glutaraldehyde (GA). To prepare the gel for formation of the membrane for glucose biosensor, the solution consisting of $7 \%$ glucose oxidase, $13 \%$ BSA, $20 \%$ glycerol in $20 \mathrm{mM}$ phosphate buffer, $\mathrm{pH} 7.5$, was used. The reference membrane gel was prepared in the same way but $20 \%$ BSA was taken instead of the enzymes. Glycerol was added to the gel to stabilize the immobilized enzyme and prevent early drying of the solution deposited on the transducer surface. BSA in the enzyme membrane served as a stabilizing agent for enzymes. Prior to the deposition, the said gels (for enzyme membrane and referent membrane) were mixed with $1 \% \mathrm{GA}$ aqeous solution at ratio 1:1.

The gel for formation of the membrane for maltose biosensor was prepared using the solution consisting of 5\% $\alpha$-glucosidase, $5.5 \%$ mutarotase, $5 \%$ GOD, $4 \%$ BSA, $20 \%$ glycerol in $20 \mathrm{mM}$ phosphate buffer, $\mathrm{pH}$ 7.5. The gel for referent membrane was made in the same way but $20 \%$ BSA was used instead of the enzymes. All prepared solutions had the same protein content.
Further procedure for both glucose and maltose biosensors was alike. After membrane deposition on the electrodes surface, the sensors were dried in the air at room temperature for $30-50 \mathrm{~min}$. Before the start of experiments, the sensors were placed in the buffer solution to washout GA excess; the further experiments were carried out in the same buffer.

Experimental setup. The interdigitated electrodes (differential pair) located in a cell with the tested solution, are supplied with alternating voltage of $100 \mathrm{kHz}$ and amplitude of $10 \mathrm{mV}$ from the low-frequency signal generator G3-118 (Ukraine). The signal obtained on sensor electrodes is taken from the load resistance $\mathrm{R}_{\mathrm{H}}=1 \mathrm{k} \Omega$, through the differential amplifier Unipan-233-6 (Poland) enters the selective nanovoltmeter Unipan-233 (Poland) and then is registered by a recording device. In experiments, dependence of the output signal amplitude on the substrate concentration was measured.

Measuring procedure. Measurements were carried out at room temperature in the potassium-phosphate buffer solution of different molarity and $\mathrm{pH}$, intensively stirred in an open cell. The sensor was first soaked for a while in the $2 \mathrm{ml}$ cell filled with the phosphate buffer solution, to obtain a steady-state primary signal, i.e. the sensor base line. A certain aliquot of the standard concentrated initial solution of the substrate was then introduced into the cell to obtain a signal to the substrate. Non-specific changes in the output signal associated with fluctuations of temperature, medium $\mathrm{pH}$, and applied voltage were compensated by using differential mode, i.e. measurement of difference between the signals from two pairs of electrodes, with active and inactive membranes, placed on the same transducer.

Results and discussion. The cascade of enzymatic reactions is a basis of the conductometric biosensor system for maltose determination:

\section{( $\alpha$-glucosidase, EC 3.2.1.20)}

$$
\begin{gathered}
\text { maltose }+\mathrm{H}_{2} \mathrm{O} \rightarrow \alpha \text {-D-glucose }+\alpha \text {-D-glucose; } \\
\text { (mutarotase, EC 5.1.3.3) } \\
\alpha \text {-D-glucose } \rightarrow \text {-D-glucose; } \\
(\text { glucose oxidase, EC 1.1.3.4) } \\
\beta \text {-D-glucose }+\mathrm{O}_{2} \rightarrow \text { D-gluconolacton }+\mathrm{H}_{2} \mathrm{O}_{2} \\
\Downarrow \\
\text { D-gluconic acid }+\mathrm{H}_{2} \mathrm{O} \leftrightarrow \text { acid residue }+\mathrm{H}^{+} .
\end{gathered}
$$




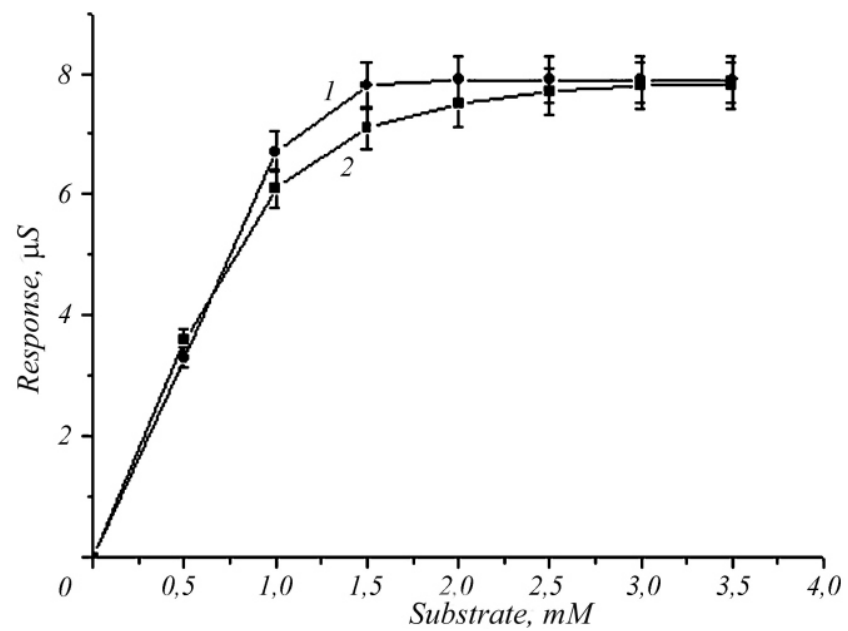

Fig. 1. Dependence of changes in conductivity of maltose biosensor on glucose (1) and maltose (2) concentrations. Measurements in 5 $\mathrm{mM}$ phosphate buffer, $\mathrm{pH} 6.5$.

$\alpha$-Glucosidase, mutarotase and glucose oxidase disintegrate maltose gradually to hydrogen peroxide and D-gluconolacton. The latter, in its turn, is hydrolyzed spontaneously to gluconic acid which dissociates for acid residue and proton, thus, the solution conductivity changes that can be registered by the conductometric transducer [17].

The graphs of dependence of the changes in conductivity of maltose biosensor on glucose and maltose concentrations are shown in Fig. 1. Measurements were carried out in $5 \mathrm{mM}$ phosphate buffer solution, $\mathrm{pH}$ 6.5. Linear range of biosensor operation was up to $1 \mathrm{mM}$, detection limit - $0.002 \mathrm{mM}$ for both glucose and maltose.

Whereas a maltose biosensor responds to both glucose and maltose, a glucose sensor is needed along with maltose one for just maltose determination, and it is two-staged procedure. First, glucose concentration in the sample is measured by glucose sensor, then summary maltose and glucose concentration - by maltose sensor, the difference corresponds to maltose concentration. Looking ahead, we assume a possibility of the simultaneous analysis as soon as the transducer with three pairs of electrodes is developed.

The changes in solution conductivity, which is known to be a basis of conductometric method, depend both on the enzymatic reaction as such and on the characteristics of the solution where this reaction takes place. That is why the influence of solution parameters

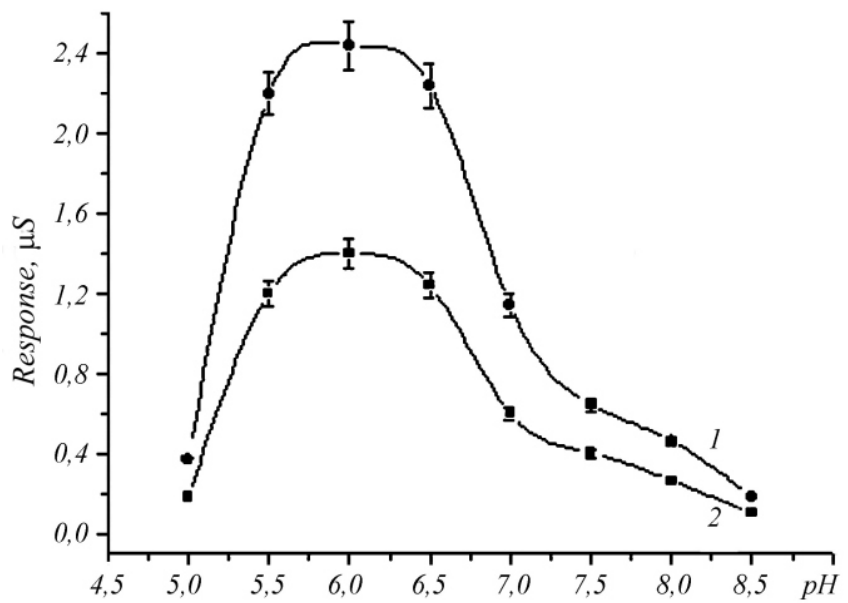

Fig. 2. Dependence of maltose biosensor responses to introduction of $0.5 \mathrm{mM}$ glucose (1) and $0.5 \mathrm{mM}$ maltose (2) on $\mathrm{pH}$. Measurements in universal buffer solution.

(ion strength, buffer capacity, $\mathrm{pH}$ ) on the sensor response was studied in the first place.

Each enzyme is characterized by its own optimum $\mathrm{pH}$. At immobilization some of them can change $\mathrm{pH}$ optimum shifting it towards either alkaline or acid region. Since we have a mixture of three immobilized enzymes with different optimum $\mathrm{pH}$, we have to find optimal $\mathrm{pH}$ of the buffer solution for work of all three enzymes.

Measurements were carried out in the universal buffer solution, which consists of mixture of different buffer solutions and has constant buffer capacity independent on $\mathrm{pH}$. The curves of dependence of the biosensor signals to introduction of $0.5 \mathrm{mM}$ maltose and $0.5 \mathrm{mM}$ glucose on $\mathrm{pH}$ were bell-shaped with the maximum at 6.0 (Fig. 2).

Dependence of the biosensor responses to maltose in buffer solutions of different concentration is presented in Fig. 3. The buffer concentration increase is seen to result in decrease of biosensor responses, considerable drop of the biosensor sensitivity to maltose whereas linear range of measurement rather raises.

Dependence of the biosensor responses to addition of $0.5 \mathrm{mM}$ glucose and $0.5 \mathrm{mM}$ maltose into buffer solutions of different concentrations (Fig. 4) demonstrates decrease in responses to glucose and maltose at increasing buffer concentration. It is a result of the raise in background conductivity of the buffer solution and its capacity, and should be taken into account in further experiments. 

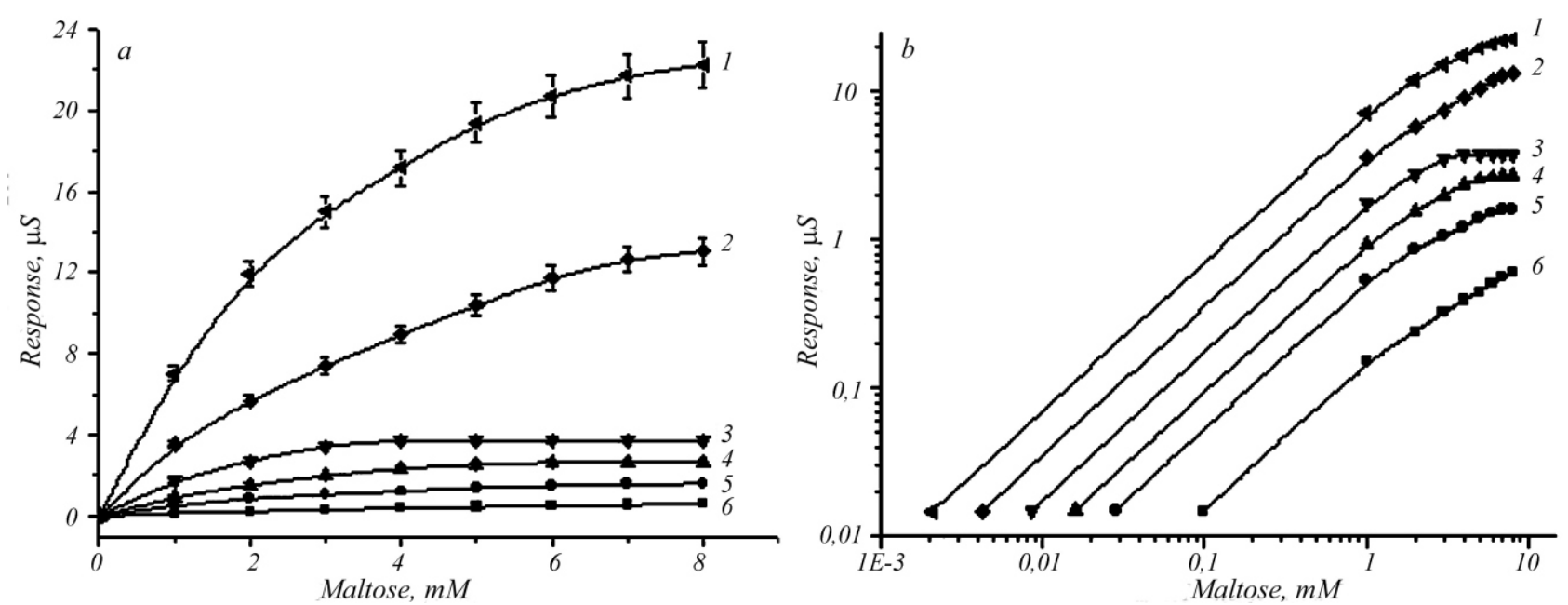

Fig. 3. Dependence of biosensor response to maltose in phosphate buffer solutions ( $\mathrm{pH} 6.0$ ) of different concentrations: $2.5 \mathrm{mM}$ ( 1 ), $5 \mathrm{mM}$ (2), $10 \mathrm{mM}$ (3), $15 \mathrm{mM}$ (4), $20 \mathrm{mM}$ (5), $30 \mathrm{mM}$ (6). $a$ - linear, $b$-logarithmic scales.

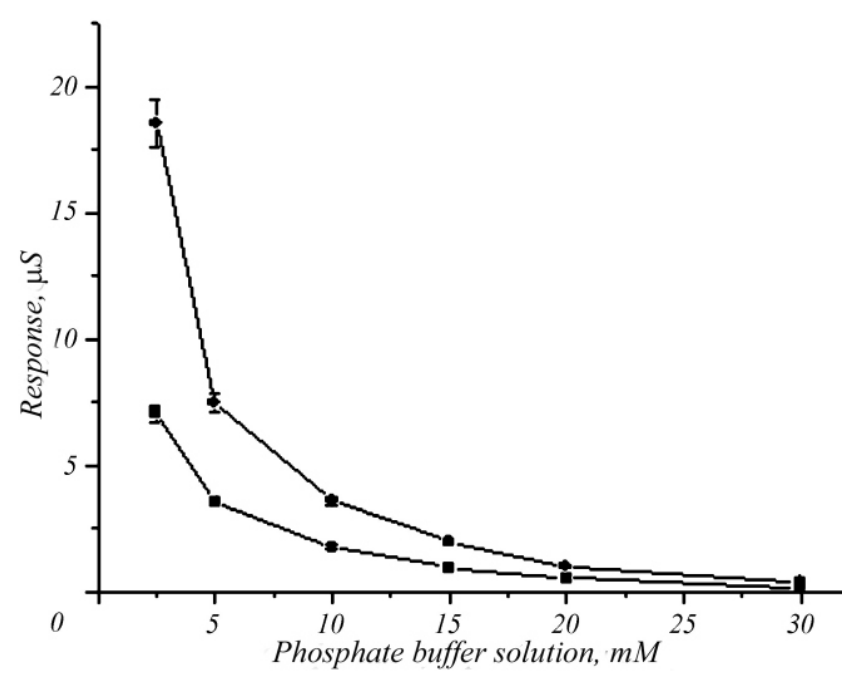

Fig. 4. Dependence of biosensor responses to addition of $0.5 \mathrm{mM}$ maltose (1) and $0.5 \mathrm{mM}$ glucose (2) on concentration of phosphate buffer solution.

Ion strength of buffer solution is an important parameter negatively influencing measurement by conductometric biosensor. To study this effect, the signals to $0.5 \mathrm{mM}$ maltose and $0.5 \mathrm{mM}$ glucose were measured while $\mathrm{KCl}$ of different concentrations was added into the buffer solution. The graph obtained (Fig. 5) shows decrease in responses at increasing ion strength: at first, considerable drop in the biosensor response is revealed; next, at $\mathrm{KCl}$ concentrations of $20-50 \mathrm{mM}$, the signal value was less than $10 \%$ of that obtained in the cell without $\mathrm{KCl}$. One of the main causes of this effect is an increase in background conductivity of the solution. So, ion strength control of the analyzed samples is important at measurement by conductometric biosensors.

Operational stability and signal reproducibility are basic characteristics of biosensors. In the experiments, the maltose concentration on the linear part of the biosensor calibration curve was taken. The sensor appeared to have high signal reproducibility (Fig. 6).

Selectivity as an essential characteristic of the conductometric maltose biosensor was studied by determination of its responce to the interfering substances. Measurements were carried out in $5 \mathrm{mM}$ phosphate buffer solution, $\mathrm{pH}$ 6.5. The interfering substances of $0.5 \mathrm{mM}$ concentration were introduced into the cell; the response to $0.5 \mathrm{mM}$ maltose was taken as $100 \%$. Selectivity of the biosensor for maltose determination:
$0.5 \mathrm{mM}$ substance

Maltose

Glucose

Saccharose

Fructose

$\alpha$-lactose

$\beta$-lactose

Mannose
Relative response of maltose biosensor (\%)

$$
100
$$

$$
4
$$

0

0

0
Basically, the tested conductometric system was shown to be selective and, thus, can be suggested for further application in the analysis of real samples. The 


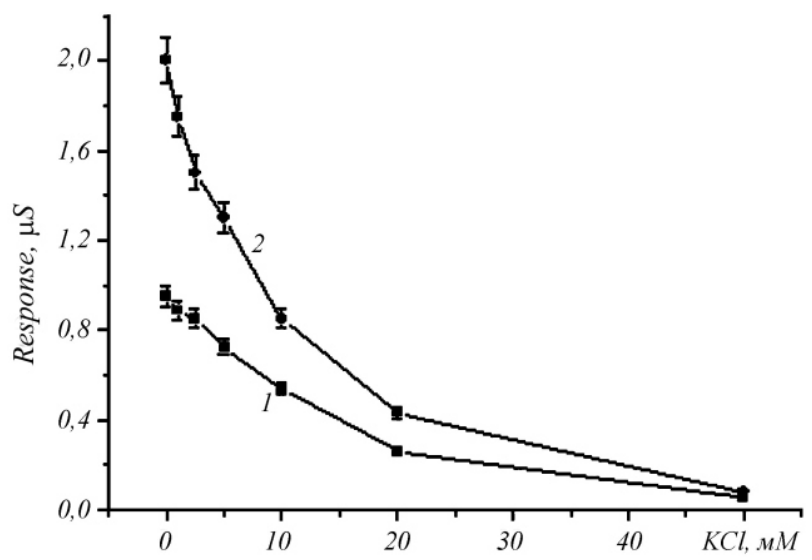

Fig. 5. Dependence of response of maltose biosensor to $0.5 \mathrm{mM}$ maltose (1) and $0.5 \mathrm{mM}$ glucose (2) on concentration of $\mathrm{KCl}$ in 10 $\mathrm{mM}$ phosphate buffer solution, $\mathrm{pH} 6,0$.

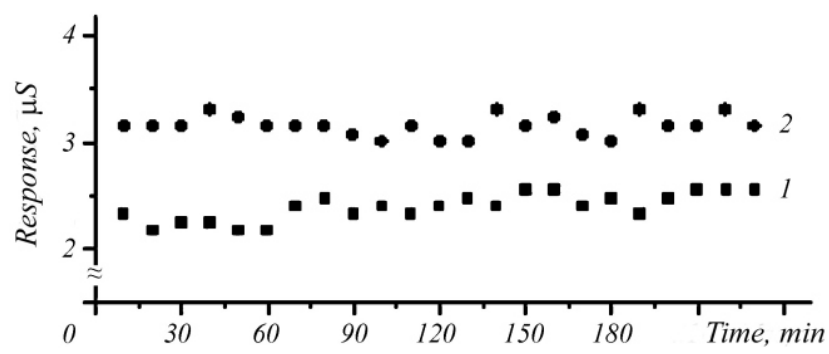

Fig. 6. Operational stability of sensor for maltose determination. Measurements in $5 \mathrm{mM}$ phosphate buffer, $\mathrm{pH} 6.0 ; 0.25 \mathrm{mM}$ maltose (1) and $0.25 \mathrm{mM}$ glucose (2) were inserted into the cell.

maltose biosensor response to glucose is quite comprehensible since glucose oxidase is a component of the enzyme membrane. This is why to measure maltose in case when glucose is present in the samples tested, another sensor, sensitive only to glucose, should be used along with the maltose one.

Conclusion. A conductometric biosensor with three-enzyme membrane as a sensitive element is developed for maltose determination, its analytical characteristics in the analysis of model samples (response dependence on $\mathrm{pH}$, ion strength, buffer capacity of working solution) are investigated. The biosensor suggested is characterized by high operational stability and signal reproducibility. Maltose determination in real samples is a goal of further study.
В. М. Пєшкова, О. Я. Саяпіна, О. О. Солдаткін, С. В. Дзядевич

Ферментний кондуктометричний біосенсор

для визначення мальтози

Резюме

Мета. Розробити ферментний кондуктометричний біосенсор для визначення мальтози. Методи. У роботі використано кондуктометричні перетворювачі, що складаються з двох пар золотих гребінчастих електродів. На поверхню останніх нанесено біоселективну мембрану, до складу якої входять ферменти глюкозооксидаза, мутаротаза, $\alpha$-глюкозидаза. Результати. Лінійний діапазон концентрації глюкози і мальтози, яку можна виявляти за допомогою кондуктометричного біосенсора для визначення мальтози, становить від 0,002 до 1 мМ. Час, потрібний для встановлення концентрації мальтози в розчині, дорівнює 1-2 хв. Досліджено залежність величини відгуку біосенсора на внесення субстрату від рН, іонної сили та буферної ємності робочого розчину, представлено дані по селективності біосенсора. Розроблений кондуктометричний біосенсор характеризується високою операчійною стабільністю та відтворюваністю сигналу. Висновки. Створено ферментний кондуктометричний біосенсор для визначення мальтози та проаналізовано його робочі характеристики. Запропоновану методику вимірювання мальтози можна застосовувати у подальшому в харчовій промисловості для контролю і оптимізації виробництва.

Ключові слова: кондуктометричний біосенсор, мальтоза, мутаротаза, глюкозооксидаза, $\alpha$-глюкозидаза.

\section{В.Н. Пешкова, О. Я. Саяпина, А. А. Солдаткин, С. В. Дзядевич}

Ферментный кондуктометрический биосенсор для определения мальтозы

Резюме

Цель. Разработать ферментный кондуктометрический биосенсор для определения мальтозы. Методы. В работе использовали кондуктометрические преобразователи, в состав которых входят две пары золотых гребенчатых электродов. На поверхность электродов наносили биоселективную триферментную мембрану (глюкозооксидаза, мутаротаза, $\alpha-$-люкозидаза). Результаты. Линейный диапазон концентраций глюкозы и мальтозы, которые возможно выявить с помошью кондуктометрического биосенсора для определения мальтозы, составляет от 0,002 до 1 мМ. Время, нужное для установления концентрации мальтозы в растворе, равно 1-2 мин. Изучена зависимость откликов биосенсора на субстрат от pH, ионной силь и буферной емкости рабочего раствора, представлены данные по селективности. Созданный кондуктометрический биосенсор характеризуется высокой операиионной стабильностью и воспроизводимостью сигнала. Выводы. Разработан ферментный кондуктометрический биосенсор для определения мальтозы и исследованы его рабочие характеристики. Предложенная методика измерения мальтозы может быть применена в дальнейшем в пищевой промышленности для контроля и оптимизации производства.

Ключевые слова: кондуктометрический биосенсор, мальтоза, мутаротаза, глюкозооксидаза, $\alpha$-глюкозидаза. 


\section{REFERENCES}

1. Magomedov G. O. Technology of caramel.-Kiev, 2008.$209 \mathrm{p}$.

2. David A. B. Dictionary of food and nutrition.-Oxford: Univ. press, 2005.-608 p.

3. Filipiak M., Fludra K., Gosciminska E. Enzymatic membranes for determination of some disacchrides by means of oxygen electrode // Biosensors and Bioelectronics.-1996.11, N 4.- P. 355-364.

4. Gondo S., Kim C., Hirata S., Morishita M. Studies on dynamic behavior of the biosensor based on immobilized glucoamylase-glucose oxidase membrane // Biosensors and Bioelectronics.-1997.-12, N 5.-P. 395-401.

5. Ge F., Zhang X. E., Zhang P., Zhang X. M. Simultaneous determination of maltose and glucose using a screen-printed electrode system // Antonie Van Leeuwenhoek.-1997.-71, N 4.-P. 345-351.

6. Menzel C., Lerch T., Scheper T., Schugerl K. Development of biosensors based on an electrolyte isolator semiconductor (EIS)-capacitor structure and their application for process monitoring. Part I. Development of the biosensors and their characterization // Anal. Chim. Acta.-1995.-317, N 1-3.P. 259-264.

7. Varadi M., Adanyi N., Nagy G., Rezessy-Szabo J. Studying the bienzyme reaction with amperometric detection for measuring maltose // Biochimie.-1980.-62, N 8-9.-P. 587593.

8. Mori T., Motonaga T., Okahata Y. Cast films of lipid-coated enzymes as selective sensors for disaccharides // Colloids and Surfaces A: Physicochemical and Engineering Aspects.1999.-146.-P. 387-395.

9. Kullick T., Beyer M., Henning J., Lerch T., Quack R., Zeitz A., Hitzmann B., Scheper T., Schugerl K. Application of enzymefield effect transistor sensor arrays as detectors in a flowinjection analysis system for simultaneous monitoring of medium components. Part I. Preparation and calibration // Anal. Chim. Acta.-1994.-296.-P. 263-269.

10. Zajoncova L., Jilek M., Beranova V., Pec P. A biosensor for the determination of amylase activity// Biosensors and Bioelectronics.-2004.-20.-P. 240-245.
11. Kullick T., Bock U., Schubert J., Scheper T., Schugerl K. Application of enzyme-field effect transistor sensor arrays as detectors in a flow-injection analysis system for simultaneous monitoring of medium components. Part II. Monitoring of cultivation processes // Anal. Chim. Acta.-1995.-300.P. 25-31.

12. Aoki K., Uchida H., Katsube T., Ishimaru Y., Iida T. Integration of bienzymatic disaccharide sensors for simultaneous determination of disaccharides by means of light addressable potentiometric sensor// Anal. Chim. Acta.-2002.-471.-P. 312.

13. Tessema M., Ruzgas T., Gorton L., Ikeda T. Flow injection amperometric determination of glucose and some other low molecular weight saccharides based on oligosaccharide dehydrogenase mediated by benzoquinone systems // Anal. Chim. Acta.-1995.-310.-P. 161-171.

14. Sun C., Zhang X., Jiang D., Gao Q., Xu H., Sun Y., Zhang X., Shen $J$. Electrocatalytic oxidation of carbohydrates at a molecular deposition film electrode based on water-soluble cobalt phthalocyanine and its application to flow-through detection // J. Electroanal. Chem.-1996.-411, N 1-2.-P. 73- 78.

15. Dzyadevych S. V., Soldatkin O. P. Conductometric method of measurements in enzyme analysis // Ukr. Biochem. J.-1994.66, N 4.-P. 30-42.

16. Dzyadevych $S$. $V$. Conductometric enzyme biosensors theory, technology and application // Biopolymers and Cell.-2005.21, N 2.-P. 91-106.

17. Dzyadevych S. V., Shulga A. A., Patskovsky S. V., Arkhipova V. N., Soldatkin A. P., Strikha V. I. Thin-films conductometric transducer for enzyme biosensors // Rus. J. Electrochem.-1994.-30, N 8.-P. 887-891.

18. Pyeshkova V. M., Saiapina O. Y., Soldatkin O. O., Kukla O. $L$., Dzyadevych $S$. $V$. Enzyme conductometric biosensor for determination of lactose // Biotechnology.-2008.-N 4.P. 76-84. 